
www.jomat.org

\title{
The regional forum of the sustainable tourism of Brejo and its Role in the interiorization of tourism in Paraíba/Brazil
}

\author{
Ana Valéria Endres
}

Keywords:

Public Tourism Policies, Tourism Regionalization Program/Brazil,

Social Network Analysis

Article History:

Submitted: 07.05.2021

Accepted: 12.12 .2021

\section{ABSTRACT}

In Paraiba, Northeastern Brazil, the sun and sea segment is the main responsible for the flow of visitors in the state, being the segment that receives the most government investments in planning and promotion, to the detriment of the interior regions that figure in the background. The main policy of Ministry of Tourism is the Tourism Regionalization Program, which aims to manage, structure and promote tourism in a decentralized manner, transferring the responsibility for its development to the tourist regions, thus opening up possibilities for the interiorization of the activity. The Paraibano Tourist Region is one of the few in the interior of the state that has a growing tourist movement and an organizational dynamism that makes it stand out from the rest. Thus, the question is: What are the determinants of interests that move between the order established by public policy and the horizontal relations, of a more organic nature, forged within the Region? Are there more or less strong indications that the actions guided by the Program and those implemented by the Regional Forum for Sustainable Tourism in Brejo have been contributing to the interiorization of tourism in Paraiba? That said, the main goal of this study is to investigate the performance of the Regional Forum for Sustainable Tourism of Brejo and its contributions to the process of interiorization of tourism in Paraiba. This is a descriptive and qualitative research that uses bibliographic and documentary data, as well as data collected in field visits. The reticular perspective was also used as a methodological resource. Data were analyzed and interpreted through the conceptual repertoire of the fields of Geography and Political Sociology for the understanding of local dynamics, guided by the verticality and horizontality imposed by public tourism policy in the Region. The conclusion reached is that the increase in tourism happens horizontally, that is, the most significant actions for regional tourism planning arise in the region, from the articulation of local actors, mainly through and around the Forum

\section{Introduction}

Talking about the interiorization of tourism in Paraíba is referring to the activity in regions located beyond the waterfront; it is to consider a movement that is limited to a few municipalities in the interior of the state, which seek to integrate as a complementary product to sun and sea tourism, the main segment responsible for the flow of visitors in the state. Tourism on the coast is what receives the most investments in planning and promotion, on the other hand, the interior regions are historically in the background with regard to the application of public and private resources.

Even so, in the second decade of the present century, there has been a significant improvement and growth in tourism supply and demand in specific regions of the interior of the state, especially in some cities in the micro-region of
Brejo Paraibano, which corresponds to a transition area between Zona da Mata (waterfront) and Sertão.(Hinterland) Its natural characteristics such as milder temperatures, morphological formation of mountain ranges and historical and cultural attributes - are configured as tourist attractions that give the region the possibility of consolidating other segments in the tourist activity in the state, in addition to sun and sea tourism.

The dynamism presented by Brejo runs parallel to the Programa de Regionalização do Turismo (PRT) (Tourism Regionalization Program), which since 2003 proclaims as its objective the tourism planning in a regionalized and decentralized way, transferring the responsibility for their own development to the tourist regions. From a policy perspective, the mandatory institutionalization of Instâncias de Governança Regional (IGR) 
(Regional Governance Instances) and the effectiveness of the articulations that involve social actors in different spheres and levels, is what determines its success. In this case, the context in which this dynamism occurs in the Brejo Region invites investigation. After all, what are the determinants of interests and different rhythms of the flow of actions that move between the order established by public policy, and the horizontal relations provided by this same order, of a more organic nature, forged within the Region?

This is the background where the main question of this work is outlined: Are there more or less strong indications that the actions guided by the PRT and implemented by the Fórum Regional Turístico Sustentável do Bejo (FRTSB) (Regional Forum for Sustainable Tourism of Brejo) have been contributing to the interiorization of tourism in Paraíba? That said, the main objective of this study is to investigate the performance of the FRTSB and its contributions to the process of interiorization of tourism in Paraíba.

Next, the chapter presents a discussion on verticalities and horizontalities for a better understanding of the spatial dynamics imposed by public tourism policy in the region. After detailing the object of study and its historical trajectory, the chapter ends with a reticular analysis of the flow of articulations that imprint a different facet on tourism planning in the region.

\section{Theoretical Framework}

Verticalities and Horizontalities in Public Policies

The words verticality and horizontality are commonly associated with geography. However, over time, other disciplines started to use these terms, according to different perspectives and purposes. In this work, the studies of the geographer Milton Santos $(2001,2006)$ are used as a theoretical basis for the understanding of such concepts, in order to later apply them to the studied reality. Thus, it will be possible to understand the relationships and effects built in the context of public policies from the verticals and horizontalities that affect the environment.

Santos (2001, 2006) defines verticalities and horizontalities as arrangements or cutouts of the current geographic space, resulting from the globalization process, positioned in an overlapping and complementary way. In this direction, in the interpretation of Goulart et al. (2010, p. 397), verticalities and horizontalities are "the fragmentations of space, its functionalities and reordering of places in geographic continuities or not”. Each category has its particularities.

Verticalities compose what Santos (2006, p. 192) calls “(...) constellations of discontinuous but interconnected points, which define a space of regulatory flows". The points that form the space of flows do not follow a continuity because they are separated at different economic and spatial levels, far from each other, on scales ranging from local to global, but when interconnected, they ensure the global functioning of society and economy, that is, of the established order.

Santos (2006) explains that local society exercises control over its technical aspects of work, while the political aspects of this work are determined at higher levels and far from the place where the macro-actors (macro companies and the State) who hold decision-making power operate about these dynamics. In these circumstances, it is observed "[...] a solidarity of the organizational type, that is, the relationships that maintain the aggregation and cooperation between the [local] agents result from an organization process [...]" (Santos, 2001, p. 106) in which external agents are directly or indirectly responsible for ordering part of the work of local actors, who, in turn, become dependent on their regulation. Verticalities imply dependent and hierarchical relationships, in which directions follow from the top down.

While in verticalities the flow points are far from each other, in horizontalities they are close and integrated. For Santos (2006, p. 192), horizontalities are "extensions formed by points that add seamlessly, as in the traditional definition of region". Due to this continuity and contiguity, horizontalities consider the regional/local scale of things in which the actors and actions are local, close, integrated, and cooperated. Horizontalities imply lateral relationships, without hierarchies and dominations, consequently, without subordination.

Horizontalities are the locus of a more limited cooperation, to the point that verticalities are the vehicle of a broader cooperation, both economically and politically, as well as geographically. In verticalities, the result is an organizational solidarity that implies a local ordering as a movement imposed by external agents. To the point that for horizontalities there is an organic solidarity, resulting from a local solidary integration based on the collective interest of the actors. Despite the different interests and rhythms, the integration between these different parts is 
precisely what maintains the survival of each one and, consequently, of the whole (Santos, 2001).

Santos (2006) clarifies that horizontalities are both the place that receives orders from distant hegemonic actors, and the place where decisions taken locally and together are processed. This means that horizontalities are the product of decisions originating on the spot, but also of vertical orders. This explains the fact that verticalities and horizontalities occur in the same space and at the same time.

The connection and fluidity in the space of horizontalized and verticalized flows are processed in a way that they can be perceived through the approach of networks, forming a reticular system. These networks act so much at the service of those actors who, from outside the area, determine the internal modalities of action in places, organizing the work of all other actors; as at the service of those actors who foster social cohesion in response to marginalization and exclusion and to the globalization process that often do not meet the development interests of a particular territory or region (Degrandi \& Silveira, 2013; Karnopp, 2014).

Based on all this, one has to think that all public policies elaborated by the central government and directed to a certain location are vertical, since they start from the top down, from the federal to the local level. But, even thought by the central government, these policies carry elements that determine horizontal practices, such as the articulation and participation of actors in the processes of formulation and implementation of government actions at the local level. The administrative decentralization undertaken by the Brazilian State starts to expose the forces that condition these processes and determine the role of actors in the conduct of national public policies, including in the context of public tourism policies.

\section{Public Tourism Policies And The Reticular Perspective}

Tourism, as it is a complex and dynamic phenomenon, which covers different sectors, causing impacts of opposite natures, awakens interests in governments, business, researchers and society in general. Therefore, naturally, tourism needs planning and specific policies for its better management.

Public policies are guided by what governments decide to do or not do, that is, situations in which they assume a position of deliberate choice in view of the possibilities of acting and not acting, deciding and not deciding in spaces where the clashes around interests, preferences and ideas develop (Hall, 2011). Planning, on the other hand, is a process through which public policies are developed, aiming to implement strategies that enable tourism development in localities, based on legitimate interventions to affect behavior and practices within precise territorial limits (Rodrigues, 2014). However, the course of rethinking and establishing tourism as a development strategy is an arduous task, which is imposed not only and exclusively on the State, but on the entire tourism production chain and on society in general (Coriolano, 2006).

From a historical perspective, Molina and Rodrigues (2001) note that the main motivation for tourism planning in Latin America, from the 1970s onwards, was concentrated on the potential benefits credited to tourism to attract investments, generate employment and income and promote economic growth, without considering the qualitative character of this growth. The planning, of an eminently technocratic and centralizing character, which oversees state actions to promote the sector, begins to be questioned due to its decontextualization in relation to the physical, economic, cultural and social aspects and the emergence of more participatory processes (Endres, 2002).

In Brazil, from 1988 onwards, with the establishment of the Citizen Constitution, the roles to be played by the government in conducting its policies are reorganized. All governments and civil society are subject to a new logic and structure of action that focuses on participation (Cohen, 2003; Côrtes, 2005). It is at this moment that discussions on governance emerge within the Brazilian State, based on the scope of managerial public administration, in order to meet the policy objectives more efficiently, given the State's slowness in responding to public problems (Keinert, 2007; Secchi, 2009).

The necessary administrative decentralization, combined with the growing desire for greater participation by civil society in decisions, allowed the opening of legitimate spaces in which they could act together, such as the public policies management councils (Carneiro, 2002; Draibe, 1998). The emergence of this context established new relationships in response to the hierarchization of centralized decisions and stimulated the formation of networks, based on the decentralizing governance established since then (Mota \& Bittencourt, 2019). 
The network perspective comes into evidence as an innovative way of conducting policies and the search for partners by the government outside the State sphere becomes strategic for the realization of the decentralization imposed for/for the consolidation of Brazilian democracy (Lavalle et al., 2007; Martins, 1998). During this period, direct democracy was strengthened by the institutionalization of different spaces in which social actors interact and articulate, fostering participatory experiences, strengthened from 2003 onwards by a more social public administration (Avritzer, 2009).

In public tourism policies, established from the 1990s onwards, networks are treated in a metaphorical and normative way under the notion of "partnerships", which ultimately supports the Programa Nacional de Municipalização do Turismo (PNMT) (National Program for the Municipalization of Tourism), launched in 1994 In the PRT, created in 2004, networks appear as a sine qua non for their implementation, as they establish new forms of articulation between various organizations of civil society and government (Endres, 2003). In subsequent years and administrations, what is observed is the expansion of network governance structures as a mechanism for political participation, whether subjugated to the dictates of the market or more social demands (Lopes \& Baldi, 2009; Lowndes \& Skelcher, 1998).

The notion that networks structure and shape new perspectives of governance begins to be evidenced by public tourism policies and becomes the focus of studies to understand the dimension of the relations between the State and society and for the legitimacy and effectiveness of these spaces within the Brazilian context (Batin et al., 2020; Endres \& Pakman, 2019).

Studies in Brazil on how the State conducts public tourism policies are not recent, but scarce until the mid-2010s (Endres, 2010), and take breath from the contributions of Hall (2011) and González (2014) on the theme of tourism governance. Some theoretical-methodological perspectives are used to elucidate its dynamics and complexity for its establishment, which ultimately have as a strategy to improve collective decision-making processes, always focused on broad benefits (Coutinho \& Nóbrega, 2019).

Based on this perception, it is understood here that governance guides the institutionalization of networks and legitimizes the articulations between actors in spaces of participation formalized and endorsed by federal policies, as can be seen in the proposed implementation of the PRT. According to the Program

Institutionalizing is the same as establishing, therefore, institutionalizing is the same as establishing. Instances are the different forms of organization that manage the Program in a tourist region. Governance concerns the act of governing, leading, governing. Therefore, the expression Institutionalization of Regional Governance Instances means to establish an organization to decide and lead the tourism development of a region (Ministério do Turismo [MTur], 2007, p. 14).

Stimulating the institutionalization of the IGR means the formal establishment of an organization that can build pacts, share spaces for dialogue, make decisions and guide the tourism development of a region in a sustainable way (MTur, 2019). However, achieving this objective depends on how actors position themselves and articulate themselves in the networks of relationships they establish with each other. In this context, the reticular perspective has a contribution to make to this discussion, as it exposes the central actors and the patterns of relationships, vertical and horizontal, that drive public policy for tourism in Brejo and that encourage the internalization of tourism in Paraiba.

\section{Methodology}

This is a fundamentally qualitative - descriptive research, whose main goal is to diagnose the problem in question through pre-analysis, exploration of the material and treatment of the data and information obtained, without necessarily presenting a solution to the problem, as is the case here in which case only a few relevant reflections are outlined. The collected material received qualitative treatment, that is, the data were analyzed and interpreted through the conceptual repertoire of the fields of Geography and Political Sociology, in order to build logical meanings to the facts related to the research problem pointed out. For this analysis, interviews and minutes of the Forum meetings were essential.

The interviews were conducted between 2015 and 2019, on different occasions. The first contact with the Regional Forum for Sustainable Tourism of Brejo, henceforth referred to as Forum, took place in 2015 in the city of Areia, at a meeting of "sensitization" of Secretaria de Estado de Turismo e Desenvolvimento Econômico (SETDE) (Secretary of State for Tourism and Economic Development) 
on the PRT and the importance of the Governance Body. On that occasion, the president of the Forum and the executive manager of support to SETDE's government programs were interviewed about their vision of the progress of the PRT in Brejo, in light of the norms established by the PRT in 2013 (MTur, 2013).

In 2016, at SETDE's headquarters in João Pessoa, the executive manager was interviewed again, as well as, on a visit to the municipality of Solânea, the still president of the Forum. Also interviewed were the municipal secretaries of Areia and Bananeiras at the time, as well as two lodging entrepreneurs who still work in the region. The last interview was carried out in 2019 with the Forum's current secretary, in the municipality of Duas Estradas, and sought to retrieve new information about the work carried out since then. Throughout the text, not all informants are identified, only some lines were selected because they are illustrative for the analysis undertaken.

These interviews were guided by a script and organized into thematic blocks in order to: (a) Identify actions designed and undertaken in the study area through the perception of actors involved in the local tourist activity on the importance of the PRT and its repercussions for the region; (b) Identify the actors involved with local actions, understand the relationships established between them and the forms of articulation of local/regional agents and/or with external agents; and finally, (c) analyze the advantages and difficulties faced by them in developing tourism in the interior of Paraíba.

The choice of informants was based on the intention of identifying and comparing the vision of some organizations that participate in the Forum meetings regarding the local tourist activity, as well as understanding how these agents act in the region, whether articulated with each other or not, in order to try to point out where the political actions that contribute to the increase of tourism in the Turistic Region of the Brejo come from.

Regarding the spheres of action in which these organizations are located, the classification proposed by Bresser-Pereira and Grau (1999) is used, namely: the state public sphere holds the power of the State and/or is subordinate to the State apparatus, also called "first sector"; the nonstate public sphere, also known as the "third sector" or "non-governmental organization", represent organizations that originated through the action of social movements aimed at the public interest, is non-profit, although governed by private law; the corporate sphere is also non-profit, but is oriented towards defending the interests of a group or corporation, that is, the interests of market representatives. There is also the private sphere, which is oriented towards profit or private consumption, being represented by entrepreneurs.

Table 1: Organizations Participating in the Forum Meetings Between 2009-2018, Divided Into Spheres of Action.

\begin{tabular}{|l|l|l|l|}
\hline \multicolumn{1}{|c|}{ STATE } & \multicolumn{2}{|c|}{ CIVIL SOCIETY } & \multicolumn{1}{|c|}{ ENTREPRENEURS } \\
\hline State public sphere & Corporate sphere & Non-state public sphere & Private sphere \\
\hline (9) BNB & $\begin{array}{l}\text { (5) Ass.de Artesãos e } \\
\text { Costureiras }\end{array}$ & (1) AJAC & $\begin{array}{l}\text { (12) Condomínio Águas da } \\
\text { Serra }\end{array}$ \\
\hline (10) Bombeiros Guarabira & (8) ATURA & (2) AMAR & (16) Engenho Baixo Verde \\
\hline (26) FUNESC & (13) Cooperativa das Flores & (3) ASSISTIC & (17) Engenho Beatriz \\
\hline $\begin{array}{l}\text { (34) P.M. de Alagoa } \\
\text { Grande }\end{array}$ & $\begin{array}{l}\text { (14) Cooperativa de } \\
\text { Bordadeiras }\end{array}$ & (4) Ass. de Jovens Arte e Cultura & (18) Engenho Lagoa Verde \\
\hline (35) P.M. de Alagoa Nova & (15) Cooperativa de Fruticultores & (6) Ass. de Mulheres do eng & (19) Engenho Mineiro \\
\hline (36) P.M. de Areia & & (7) Associação IRRIGATERRA & (20) Engenho Olho D'Água \\
\hline (37) P.M. de Bananeiras & & (27) Grêmio Morenense & (21) Engenho Serra Preta \\
\hline (38) P.M. de Belém & & (54) SEBRAE & (22) Engenho Triunfo \\
\hline (39) P.M. de Borborema & & & (23) Engenho Vitória \\
\hline (40) P.M. de Matinhas & & & (24) Engenho Volúpia \\
\hline (41) P.M. de Pilões & & & (28) Hotel Vale do Paraíso \\
\hline (42) P.M. de Pirpirituba & & & (29) IG Empresas \\
\hline (43) P.M. de Remígio & & & (30) Oficineiro do MDF \\
\hline (44) P.M. de Serraria & & & (31) Operadora Raízes Clube \\
\hline (45) P.M. de Solânea & & & (47) Pousada Rural Sítio Sabiá \\
\hline (46) PBTUR & & & (48) Pousada União \\
\hline (49) PRODETUR & & & (50) Restaurante Baião \\
\hline (55) SECULT & & & (51) Restaurante São João \\
\hline (56) SETDE & & (52) Restaurante Vila Real \\
\hline
\end{tabular}

Notes. 1) PM = City Hall. 2) Numbers before names are codes for lattice analysis. Numbers 11, 25 and 33 were excluded for technical reasons.

Source: Own elaboration (2021), inspired by Bresser-Pereira and Grau (1999, p. 16) and adapted to the Forum's reality in Paraiba. 
Based on this classification, the actors representing the State and civil society, who relate to each other from the Forum, were divided as can be seen in Table 1.

It should be noted that the organizations listed in Table 1 were those that were on the attendance lists and in the contents of the minutes of the meetings held between 2009 and 2018, which were provided by the then president of the Forum in 2016 and complemented by the secretary of the Forum, in an interview in 2019. The content and the presence list of the analyzed minutes present the historical trajectory of the actions carried out within the Forum, however, not all meetings were registered and when registered, some did not contain the relation of the presence of the participants. This explains the time gaps following the meetings shown later by the sociogram in Figure 01 before 2009, between 2011 and 2014 and between 2016 and 2018.

In an Excel spreadsheet, the dates of the meetings were entered in the columns and rows of all organizations, firstly sorted alphabetically and then enumerated. This strategy was used so that it was not necessary to include their names in full in the sociograms, making it difficult to visualize and analyze the network. This spreadsheet only shows the existence of a membership relationship of the actors in the meetings, without taking into account their attributes, which are coded in a separate spreadsheet.

In sociograms (graphical representation that represents the structure of relationships in a group situation), attributes or characteristics can be visualized, which are represented by colors and shapes of nodes or points that connect the actors. The colors, chosen at random, represent the organizations' sphere of action, with red being chosen for the public-state sphere, blue for the corporate, green for the non-state public sphere and the color yellow for entrepreneurs. Table 1 precisely shows the division of organizations by spheres of action and their respective colors. Another important attribute for the analysis is the scope of action, identified by the geometric shape of the node, so that the triangles are the local actors (organizations) with headquarters and operations in the region and the inverted triangles represent those that act at the state/national level, in addition to the region.

After the proper coding, the spreadsheets were inserted into the Ucinet 6 for Windows software (Borgatti et al., 2002) and generated an incidence matrix, with the links between the actors and the events (two-mode) and from this, an adjacency matrix, with the links established between the actors (one-mode). Through statistical models, this last matrix allowed us to dimension the degree of centrality and intermediation of the actors in the network (Hanneman, 2001). Both matrices generated sociograms (Figure 1,2 and 3) that graphically express the pattern of social relations between organizations that know and influence each other within the Forum.

According to Marques (2000) there are three important aspects about the analysis of social networks in the field of social sciences. The first concerns an older and more widespread concept in the analysis of social networks, which is to consider it as a metaphor. In everyday language, the use of the notion of network is loaded from these metaphorical registers - the interweaving, circulation, topology - to designate the sets of individuals and the relationships they maintain with each other. The second, in a more normative tradition, observes social networks as a configuration of a set of entities that seek to achieve some goals. The third sees in social networks a method for describing and analyzing the patterns of relationship in the structure of organizations and individuals in society. It is in this last aspect that this study fits clearly, considering that it best goes to the essence of the observed phenomena.

Thus, Social Network Analysis (ARS) is used as a methodological tool to support the chosen theoretical framework, which together were fundamental to build the historical trajectory of political actions in this space of participation for the interiorization of tourism in Paraíba. The patterns of relations between the actors can indicate the possibilities for the expansion or reduction of verticalities and horizontalities in the dynamics of politics and its consequences for the dynamization of regional tourism, which is precisely what we want to explain. In this sense, governance and the reticular perspective, understood as the order established and given by macro-actors, are independent variables of analysis that try to contribute to this explanation.

In the scheduled meetings, in addition to the minutes, other documents were also collected, such as the final versions of the Statute and the Internal Regulations, official letters exchanged between the Forum and other organizations, invitations, reports, summons for meetings, individual files of the members and several isolated records of 
activities and actions carried out. On the first visit, in addition to printed documents, a flash drive with most of these documents was also made available by the president at the time, which greatly contributed to the research. On the second visit, only printed documents were digitized, indicating a much lower number than those collected two years earlier. The precarious archiving of these may be a consequence of the absence of their own headquarters, which means that the elected secretaries carry with them a wealth of documents on the organizational life of the Forum, in addition to depending on the meager structures of the municipalities where they reside and seek support.

Although available, not all documents could be included in the analysis as they lack basic information such as the dates of events, showing a pattern that sheds light on the way each administration conducts and administers the Forum. It was observed that the viable documents are grouped between the years 2009 to 2011, from 2014 to 2016 and some from 2018 and from them it was possible to prepare Tables 1 and 2 that show, respectively, the Forum participants and their spheres of action and their transit as effective members of the Forum.

The research techniques used were intended to develop convergent lines of investigation based on what Yin (2004) calls data triangulation, as various sources of evidence essentially provide several evaluations of the same phenomenon that corroborate the validity of the construct. In the analysis, it was decided to do a reflective reading, based on a dialogic movement between the theoretical input and the data obtained, so that it was possible to answer the main question that guides this study.

\section{Analysis and Discussion}

\section{The Context of Tourism Policies in Paraíba}

In Paraíba, public tourism policies are undertaken by the Companhia de Desenvolvimento da Paraíba (Company for the Development of Paraíba) (CINEP), an autarchy linked to the SETDE, which aims to promote the development of the state, acting as a facilitator in the implementation of companies and projects. Examples are the construction of the Ronaldo Cunha Lima Convention Center (already partially built and in operation) and, more recently, at the end of 2020 , the relaunch of the Cabo Branco Touristic Pole (a project that has been trying to be implemented in the state since the 1980s) to be endowed with large hotel and entertainment developments. This last initiative strongly demonstrates the maintenance of the logic of tourism megaproject policies that guided tourism policies in the 1980s around the world and that had a strong impact on coastal areas in the Northeast region of Brazil.

Linked to SETDE is also the Executive Secretary for Tourism, which aims to conduct tourism planning in the state and this is done, at the moment, following the guidelines of the PRT, when trying to articulate the municipalities of Paraíba in Regions Tourism, sensitizing them to work together through IGR, as advocated in the ministerial proposal for Roteiros do Brasil started in 2003. Despite its importance for the operational function it represents, this Secretariat has no direct participation in strategic decisions for the development of tourism, leaving this role to CINEP and the Empresa Paraibana de Turismo (Paraibana Turism Company) (PBTUR), its subsidiaries (2014).

PBTUR, a mixed economy company, which has the government as its only budgetary source, is the public responsible for the tourist promotion of the state and who, in fact, promotes initiatives aimed at the development of tourism, mainly through agreements with the Minitério do Turismo (MTur) (Ministry of Tourism) and the sector's professional associations (Endres, 2014). Its initiatives are almost entirely aimed at promoting tourism on the coast.

From what has been exposed so far, we have the following picture: a region in the interior of the state that has been gaining notoriety in terms of tourist activity amid specific actions of a federal public policy - PRT - that opens up the possibility for the interiorization of tourism. However, this is implemented by a public body with low political capital and institutional capacity, in contrast to the strong investment in the waterfront headed by bodies with greater autonomy and power. Therefore, it is necessary to question the nature of this movement that has been taking place in the Turistic Region of the Brejo, in the midst of such an adverse context.

In this context, adversity is also evident in the movement that the place demonstrates to establish in the face of political arrangements determined in higher instances and resulting from the globalization process that affects the tourist industry. In the case of the Northeast, the established order is translated into structuring public policies, designed and prescribed within the scope of supranational organizations to guide local 
development. Included in this scope are national programs such as the megaproject policies in the 1980s, the Programa de Desenvolvimento do Tutismo (PRODETUR) (Northeast Development Program) since 1992 and, more recently in 2008, the PRT Inductor Destinations Management Project, all with the clear objective of introduce and reproduce on the coast the type of touristification characteristic of coastal tourism centers in Europe (especially Spanish beaches) and in America, with the example of Cancun, Mexico. In this scenario, the coast ends up being the first investment option among public administrators and entrepreneurs.

However, no matter how great the political forces for the concentration of investments on the coast, the possibilities for the development of other tourist segments in new regions, in addition to the waterfront, are beginning to be outlined. In the proposal of this rearrangement, the place takes on a prominent position, against hegemonic in that it seeks to reorganize its functionalities dictated by the established order, where the local society only exercises control over the technical aspects of work, while the political and the decision-making power of this work is determined in other instances, far from the place. In Brejo, what is observed is a counter-flow movement, which can define new dynamics based on actions that, even vertically oriented, arise from the interests and decisions of agents in the region itself.

It is also worth highlighting here the role of institutional agents representing the state, nonstate, corporate and private spheres and the relationships they establish in the process of making policy. One of the basic precepts that governs these relationships is the articulated and networked action of these agents for the implementation of the policy and the achievement of its objectives, private and/or collective. The bet is the effectiveness of working together, which is measured by participation in the arenas opened by the adopted network governance structure, but which, in the end, only yields results when supported by relationships of trust between its members. The diversity and commitment of the actors in the flow of decisions is what can indicate the reasons for the dynamism and growth of tourism in the interior.

\section{The PRT and the Brejo Tourist Region}

The Tourism Regionalization Program - Roteiros do Brasil was launched in April 2004 in an environment of political changes initiated in 2003 during the first term of the Inácio "Lula" da Silva Government (2003-2006) to replace the Programa
Nacional de Municipalização do Turismo (PNMT) (National Program for the Municipalization of Tourism) (1994-2002) of the Fernando Henrique Cardoso are. Its implementation and results were relatively positive due to its pioneering spirit in terms of decentralizing actions and encouraging the participation of various interest groups in the sector's planning process (Brusadin, 2005).

In addition, the PNMT was a structuring tourism policy that did not focus only on the coast, presenting itself as a first proposal for the interiorization of northeastern tourism. The difference, however, between both programs lies in the territorial approach. While the PNMT motivated the development of tourism planning in the municipalities, the PRT guides towards the structuring of tourist regions as a way to cover and integrate a greater number of municipalities. The change from the successful PNMT to the PRT replacement on these technical bases, however, does not mask the political issues of this decision, as tourism was the only sector of the new government's policies not to be supported by the principle of municipalization.

The PRT aims to support the management, structuring and promotion of tourism in a regionalized and decentralized manner, directing the focus of public policies to tourist regions, so that they become responsible for their own development from the institutionalization of the IGRs. The premises of the territorial approach, integration and social participation, inclusion, sustainability, innovation and competitiveness (MTur, 2007; 2013; 2019) are tested by studies such as those by Gomes and Silva (2017) in Rio de Janeira and by Silva and Fonseca (2018) and Virgínio and Ferreira (2013) in Rio Grande do Norte, in order to reflect on the prospects for the interiorization of tourist activity.

The contours of the Tourist Regions are defined based on the fulfillment, by the municipalities, of the guidelines indicated by the program. In Paraíba, the articulations between city halls, businessmen and others interested in the activity for the definition of the first Tourist Region of the Brejo took place after a call from SETDE and MTur in 2004. As at that time, some managers had already moved municipal authorities and businessmen to prepare the route for the Caminhos do Frio (Paths of the Cold) it was agreed that the municipalities that would make up the region would be those that were already articulating for the planning of the event. 
In the years that follow, new criteria are adopted to make the municipalities show commitment to play their role in the implementation of the PRT and, when met, are able to integrate a tourist region. The state government, after analysis, accepts or not the municipality's entry into the Regionalization Map released by the MTur, in principle, every two years. The Figure 1 shows the Tourist Map of Paraíba in 2019.

Figure 1: Tourist Map of Paraíba, With Emphasis on Tourist Regions in 2019

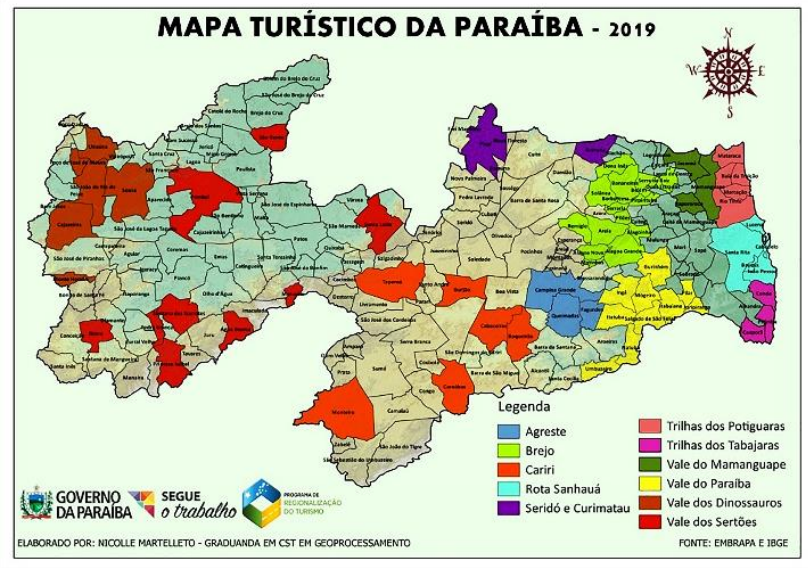

Source: www.pbtur.gov.br (2021).

However, the criteria for the entry of municipalities in the region in the Forum and, consequently, in Paths of the Cold followed another logic of action, based directly on local articulations.

Brejo's tourist products are cultural and gastronomic events that integrate several municipalities and that are conceived by the Thematic Chambers opened by the Forum, responsible for their planning. In June, the script for "Arraiá do Brejo" takes place, organized in an integrated manner, where each municipality invests in a different product. Bananeiras (37), for example, plays São João Pé de Serra, and Remígio (43) bets on the performance of square dance bands. There is a consensus among the municipalities that, separately, are not able to compete with the "Greatest São João in the World" event held by the municipality of Campina Grande, but understand that they benefit from it due to the tourist flow it generates. The regional cuisine motivated the creation of the Banana Tree Gastronomic Festival, which served as inspiration for the Festival Sounds and Flavours of Brejo Paraibano, which has been taking place since 2013. In addition to these, there are other events and actions carried out, albeit of a smaller proportion.

The main attraction of the region is the Paths of the Cold, a route with great local and regional repercussion that gives visibility to the Brejo and the municipalities that participate in it. Its first edition took place in 2005, even before the creation of the IGR, in the city of Bananeiras and in 2020 it would have been in its fifteenth edition if it were not for the Sars-CoV-19 pandemic that forced the event to be postponed. The itinerary takes place between the months of July and August, when temperatures are milder in the Brejeiras mountains, where a city each week hosts the event. The proposal is to consume the culture in the cold mountains of Paraíba through musical, theatrical, dance, handicraft attractions, in addition to exploring the regional cuisine, the rich historical heritage and the mountain landscape. A broad program that includes urban and rural spaces in the region's municipalities, as can be seen, by way of example, in the event dissemination folder of Paths of the Cold (Figure 2).

Figure 2: Folder to Publicize the General Programming of Paths of the Cold (5th Edition, 2010)

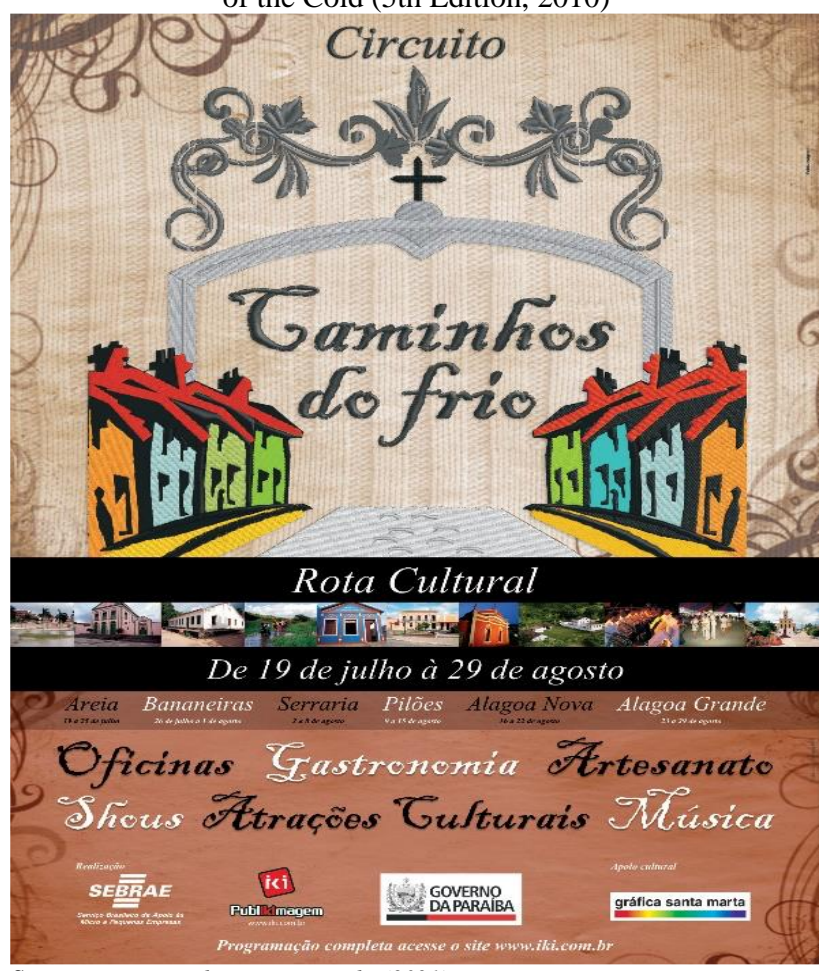

Source: www.paraibacriativa.com.br (2021).

It should be noted that the entry and exit of municipalities on the route are defined by the Forum, which receives proposals from municipalities, whether or not members of the defined region. In the words of some interviewees, the inclusion of municipalities in Paths of the Cold has been conditioned to possible facilities for obtaining support and financial resources between them and with the state and federal government, development agencies and the like. The stimulus for the insertion of new municipalities belonging to 
the Brejo Region to integrate Paths of the Cold, according to the President of the Forum, is an attempt to "join forces" to seek improvements in the infrastructure of goods and services, as well as other investments that foster and stimulate the interest and participation of the private sector in the development of tourism. In addition, the tourist potential of other municipalities that are not yet part of the event could make the overall program richer and more diversified. But, in general, only the municipality that manages to gather resources and participating companies participates in the event. For example, in 2010, six municipalities were included in the annual program.

The first edition of Paths of the Cold took place in 2005 in the city of Bananeiras, in the format of a seminar. Afterwards, the event gained shape and strength. In 2011, the Forum managed the first fundraising with the state government, through the Secretaria de Estado da Cultura (SECULT) (State Secretary for Culture) (55) for its realization, only possible by the legal formalization of the Forum in 2010. In 2013 Paths of the Cold now has nationally known artistic attractions, demonstrating better structuring, however, the crisis established in the country from 2014, and especially in 2015, resulted in the end of the resources provided by the state government and made the event become search for local artists.

The return to the place, which at first seemed to be an obstacle to the visibility of the event, came to meet the still incipient experience tourism, now established as the main segment of the Brejo (de Oliveira, 2018; Nagabe, 2019). In this sense, the partnership with the Serviço Brasileiro de Apoio às Micro e Pequenas Empresas (SEBRAE) (Brazilian Micro and Small Business Support Service) (54) was important to mobilize local entrepreneurs, through training and consultancy, in order to qualify the enterprises to receive tourists throughout the year.

In 2014, PBTUR carried out a single comparative study between the years 2011 to 2014 on the profile and habits of tourism demand in seven municipalities with an emphasis on support infrastructure, attractions, equipment and services directly associated with the activity (PBTUR, 2014). Although the data are not current, nor are they particularly reliable, they show an increase in the flow of tourists in the region in the period. Unfortunately, there is no recent systematized data that can account for this movement, much less determine the economic and social advances that contribute to regional and sustainable development based on tourism.

The Brejo Regional Sustainable Tourism Forum (FRTSB) In 2007, the MTur produced a collection of technical-guiding documents called "Tourism Notebooks", with step-by-step instructions to guide the implementation of the program at the regional level and guide actors in achieving the objectives proposed by the Tourism Regionalization Program. The Operational Module 3 notebooks (MTur, 2007) indicates the main legal forms for the institutionalization of IGRs, such as Associations, Councils, Forums, Committees and Consortia, and aspects of their applicability, form of creation, representation, administrative process, procedures and routines. The Program also advises that preference should be given to taking advantage of already established participation spaces, such as the PRODETUR (49) and the Operational Technical Groups that already work within the limits of the Regions Touristic.

The PRT encourages these spaces to incorporate regionalization activities into their attributions, in order to reconcile their strategies, when necessary and possible, and reinforces the well-known maxim that "I must keep in mind that, in order to produce results, the way in which a group organizes itself" (MTur, 2007, p. 17). This is what also reinforces the 2019 document (MTur, 2019), that a model that can facilitate the institutional relationship between city halls and between them and the private sector must be adopted, including for the feasibility of financial transfers to the actions of the IGR. For this, it is recommended to carry out a technical analysis of the advantages and disadvantages of each legal form to suit the regional characteristics before choosing one of them.

In the case of the Brejo Tourist Region, the constituted IGR is the FRTSB, defined as a civil society organization, with legal personality of private law and public interest, non-profit and economic. It was legally established in 2007, having as founding members a group of local entrepreneurs and the municipalities of Areia (36), Alagoa Grande (34), Alagoa Nova (35), Bananeiras (37), Pilões (41), Serraria (40) and Matinhas (44). In 2010 and 2011 the Bylaws and Internal Regulations were approved, respectively (FRTSB, 2010; 2011). Its establishment opened up the possibilities for making agreements, establishing partnerships, preparing and submitting projects and raising funds, among other actions that allow the IGR and its members more autonomy to carry out regional tourism planning. 
The Forum was chosen as a legal form because it is a broader, flexible and more comprehensive possibility of governance, which can act integrated with other forms of governance, such as local associations and cooperatives, in advising on the development process of regional tourism. The Forums are multiple and public spaces, where actors meet to discuss a given subject through thematic chambers, on the creation of agendas and discussion agendas, political, social, cultural and economic articulation, in order to propose and organize collective activities, without the ties of the legal structure of the others (MTur, 2019).

The Forum's Internal Regulations define that any individual and legal entity of public and private law, of unblemished reputation, committed to its statutory objectives may be associated. The duties of the associates, founders and effective:

1. Participate, as much as possible and according to your interests, in events and projects promoted by the FRTSB-PB (seminars, fairs, courses, lectures, solidarity actions, activities and social responsibility, etc.).

2. Periodically provide the FRTSB-PB, on demand, with information about your company and the results achieved, to be used in a consolidated manner together with data from other member companies and thus obtain an overview of the economic and social advances that the Association's members have made are conquering.

3. Communicate FRTSB-PB to the product and service lines it develops and or sells, the sales and marketing strategies it adopts to promote its business.

4. Pay, on the established date and in accordance with the current table, the membership fee in accordance with its category and size, defined in article 31 and its paragraphs.

5. Share with FRTSB-PB efforts to seek any kind of lost fund value and investment and promotion resources from government agencies and private institutions. (FRTSB, 2011, p. 2).

Table 2 shows Forum members with voice and voting rights, in the three available years, and lists all actors, including partners and members, by sphere of action, as defined in Table 1 above. It was built from two minutes (2007 and 2011) that registered the founders and staff linked to the Forum, while the third column was assembled from a single document prepared in 2015 among those assigned. As of that year, no relationship was found that could be systematized and included in Table 2 .
Table 2: Effective Members of the Forum with Voting and Voice Rights and Partners (Selected Years)

\begin{tabular}{|l|l|l|l|}
\hline Non-state public sphere & 2007 & 2011 & 2015 \\
\hline
\end{tabular}

(1) Associação de Jovens Arte e Cultura -
AJAC

(2) Ass. de Moradores que Amam Areia -

AMAR

(3) ASSISTIC

(4) Associação Cultural Agrícola de Jovens

(6) Associação de Mulheres do Engenho

(7) Associação Irrigaterra

Casa do Turista de Bananeiras

Diosece de Guarabira

FACINART

(27) Grêmio Morenense

Ponto de Cultura de Bananeiras

(54) SEBRAE

\begin{tabular}{|l|l|l|l|}
\hline Private sphere & 2007 & 2011 & 2015 \\
\hline
\end{tabular}

\begin{tabular}{|l|l|l|l|}
\hline Ateliê A Talha & & & \\
\hline Balne & & & \\
\hline
\end{tabular}

Balneário Furnas

Brejotur - Agência de Viagens

Cachaça Sabor da Terra

Churrascaria e Cachaçaria Vila Real

(12) Condomínio Águas da Serra

(16) Engenho Baixa Verde

(17) Engenho Beatriz

Engenho Carro

(18) Engenho Lagoa Verde

(19) Engenho Mineiro

(20) Engenho Olho D'Água

(21) Engenho Serra Preta

(22) Engenho Triunfo

(23) Engenho Vitória

(24) Engenho Volúpia

Hotel Serra Golfe

(28) Hotel Vale do Paraíso

(29) IG Empresas

Irmão em Trilha

Private sphere

Kalangos do Brejo

(30) Oficineiro do MDF

(31) Operadora Raízes Clube

Panificadora El-Shaday

OPS Produtora Cultural

Pousada Aconcheg'art

Pousada da Estação

Pousada Luis Soares

(47) Pousada Rural Sítio Sabiá

(48) Pousada União

Rancho Nova Vida

(50) Restaurante Bianão

Restaurante Pesque e Pague

(51) Restaurante São João

(52) Restaurante Vila Real

(53) Rota Turismo

Trajjeturs Turismo

Note. The actors present in the table are all those who appear in the minutes (preceded by the number) and those identified in other Forum documents, with the exception of the minutes. Among all those mentioned, the table highlights in green only the effective members, defined by the Assembly, for a specific period. Source:

Prepared by the author based on Forum documents (2021). 
Regarding Table 2, it should be remembered that among the documents obtained after 2015 there were a good number of handwritten forms with registration of members, but they were not dated, but indicated that they were from different periods due to the different layout of the forms. Mostly, they registered the association of small enterprises such as bars, restaurants, producers of local events, tourist agencies, grocery stores and others located in several municipalities in the region, as well as liberal professionals who are not included in the table nor appear in the minutes. This group represents the majority of members who pay their contribution but do not participate in Forum meetings, at least not in those that have been registered.

The data in Table 2, even with the limitations pointed out, show that the participation of the public sector is more stable, especially of the more active group that participates more in the editions of Paths of the Cold; that in the private sphere only the largest companies have more sensitive continuity while the small ones, even though they are the majority, appear and disappear, having sporadic participation in the meetings, which can be seen in the sociogram in Figure 3 later in the text.

The discontinuity of the payment of the annuity is a factor that greatly influences the entry and/or exit of organizations and individuals as effective members of the Forum. The categories subject to membership are divided between city halls, associations, cultural groups, clubs/associations and individual entrepreneurs. With the exception of city halls that pay more, the annual fee is the same for the other categories. The issue of default is a recurrent theme at the meetings, as the annual fee is what sustains a large part of the Forum's expenses and activities.

Many of the documents collected show the Forum's daily life in terms of accountability, defining planning and evaluation strategies, encouraging institutional strengthening actions and, relentlessly, seeking new members and partners such as public bodies, development and training agencies, companies, individual entrepreneurs and politicians, with the clear objective of obtaining resources and establishing partnerships.

The movement of Forum members gives the IGR a different dynamic from the results of the studies carried out by Xavier et al. (2021) on the difficulties in conducting the Regional Tourism Forum of the Central Region, in Rio Grande do Sul, in generating mobilization and collective involvement. It also distances itself from the perception of Nóbrega and Figueiredo (2014) of the IGRs in western Pará, with emphasis on the Foretur/Tapajós, which does not satisfactorily address basic governance elements, such as the quantity and quality of established partnerships. In an opposite perspective to these results, the Forum of Brejo approaches the understanding that the choice of the forum as a legal form favors more dynamic, agile and less bureaucratic actions that give the opportunity and autonomy of its members to perform their roles (Costa \& Carvalho, 2014).

This situation leads to a reflection: what are the implications of this choice for the establishment and consolidation of network governance? What characteristics of networks do the Forums reinforce? Would other institutionalization modalities bring a different aspect to their conduct? How does the institution of the Forum contribute to facilitating synergy and the exchange of resources to decide and drive the growth of tourism in the region? Are there signs that the legal character affects the analysis of the effectiveness of participation in formally instituted spaces? So far, little is known whether the quality of participation (in)depends, in principle, on the structure and format of law chosen by the regional collective represented by the public, non-state public, corporate and private sectors, which are related through this policy.

The studies carried out on the performance of IGRs in various formats of legal grouping, such as legally called Councils, Associations, Development Agencies, Forums and others, were not sufficiently systematized to be able to state whether the chosen legal modality affects the effectiveness of the spaces of participation, legitimized by the governance structure given by the PRT. Furthermore, converging with what the Program states, it is understood that "the institutionalization of the IGR, in fact, will occur when, in addition to complying with legal and institutional aspects, it will be known and recognized by the regional community, in particular by the actors that make up the Tourist Trade and by institutions that have relations with these representatives" (MTur, 2019, p. 9). This is the idea.

\section{Analysis of the Forum from the Reticular Perspective}

The Forum, even before its formalization as an IGR in 2007, had as its agenda to mobilize city halls, companies and other organizations interested in the development of tourism in the region to build 
Figure 3: Sociogram of Membership (Two-Moden) of Actors Present at Forum Meetings Regional Sustainable Tourism of Brejo Between the Years 2009 To 2018

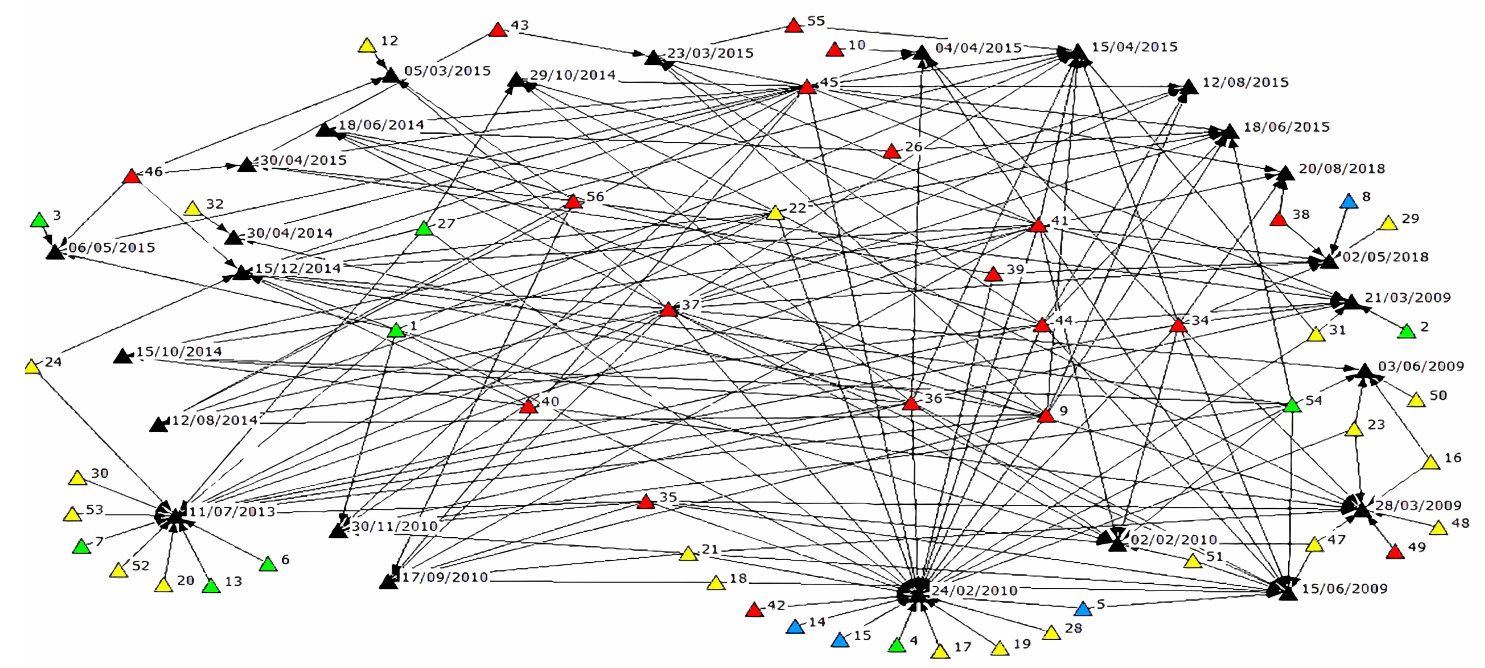

Source: Prepared by the author (2021).

"partnerships" in the planning of Paths of the Cold. The theme of the meetings, preponderantly, revolves around the planning of the event and the demands for its realization.

It is in this space of participation that the search and maintenance of partnerships and fundraising strategies are articulated with the tourism development entities that open up to these possibilities, whether in the planning of Paths of the Cold, or in the offer of training courses for local entrepreneurs, or for the improvement of infrastructure and promotion of the region.

The first sociogram (Figure 3) shows the pattern of relationships established between organizations as a result of their presence in meetings - represented by black triangles with the respective dates of events - held by the Forum between the years 2009 to 2018. These organizations are represented in the sociogram by the colored triangular nodes or connection points, the state public sphere being the red color, the non-state public sphere the green color, the corporatist blue and the entrepreneurs the yellow (in line with the colors assigned, for each sphere, in the Table 1).

At the bottom of the network, one can see, between the meetings held in 2009 and 2013, the presence of some organizations representing the corporate sphere, which over the years disappeared from the meetings. The exception is the Associação de Turismo Rural e Cultural de Areia (Rural Tourism Association of Areia) (ATURA) (8), which despite appearing only at the meeting on May 2, 2018, begins to play an important role in the dynamization of the Forum, as measured by the analysis of other documents and by the speaks of some interviewees. Its creation in 2014 was stimulated by the consultancy provided by SEBRAE (54) to the Forum on associations in the municipality, which in previous years also contributed to the organization of various cooperatives (such as those formed by artisans, fruit growers, embroiderers and seamstresses) scattered around region and who once participated in the meetings.

The role of the owner of Engenho Triunfo (22), the first to open the doors for visitation, inaugurating a new modality for local tourism was decisive for the mobilization of Areia's businessmen to organize themselves. The presence of representatives from the private sphere (plant owners, small businesses and individual micro-entrepreneurs) at the Forum is constant, considering that a large part of the board and founding partners come from this sphere of activity, who are often present, in different roles. An example is the case of ATURA (8) and Engenho Triunfo (22), Solânea City Hall (45) and IG Companies (29), actors who take turns representing private, public, and public sometimes the corporate. From the perspective of all these actors, the Forum is an alternative to be heard and attended to in demands for more investment in tourism in the region.

At the top of the network are arranged the meetings held between 2014 and 2015, a period in which local and regional articulations made a difference in the organization and execution of the 2015 edition of Paths of the Cold, which ended up contributing to a particular movement in region. Some members of the Forum, together, took the 
Figure 4: Sociogram of the Degree of Centrality of Actors in the Regional Forum Network of Sustainable Tourism of Brejo Between the Years 2009 To 2018

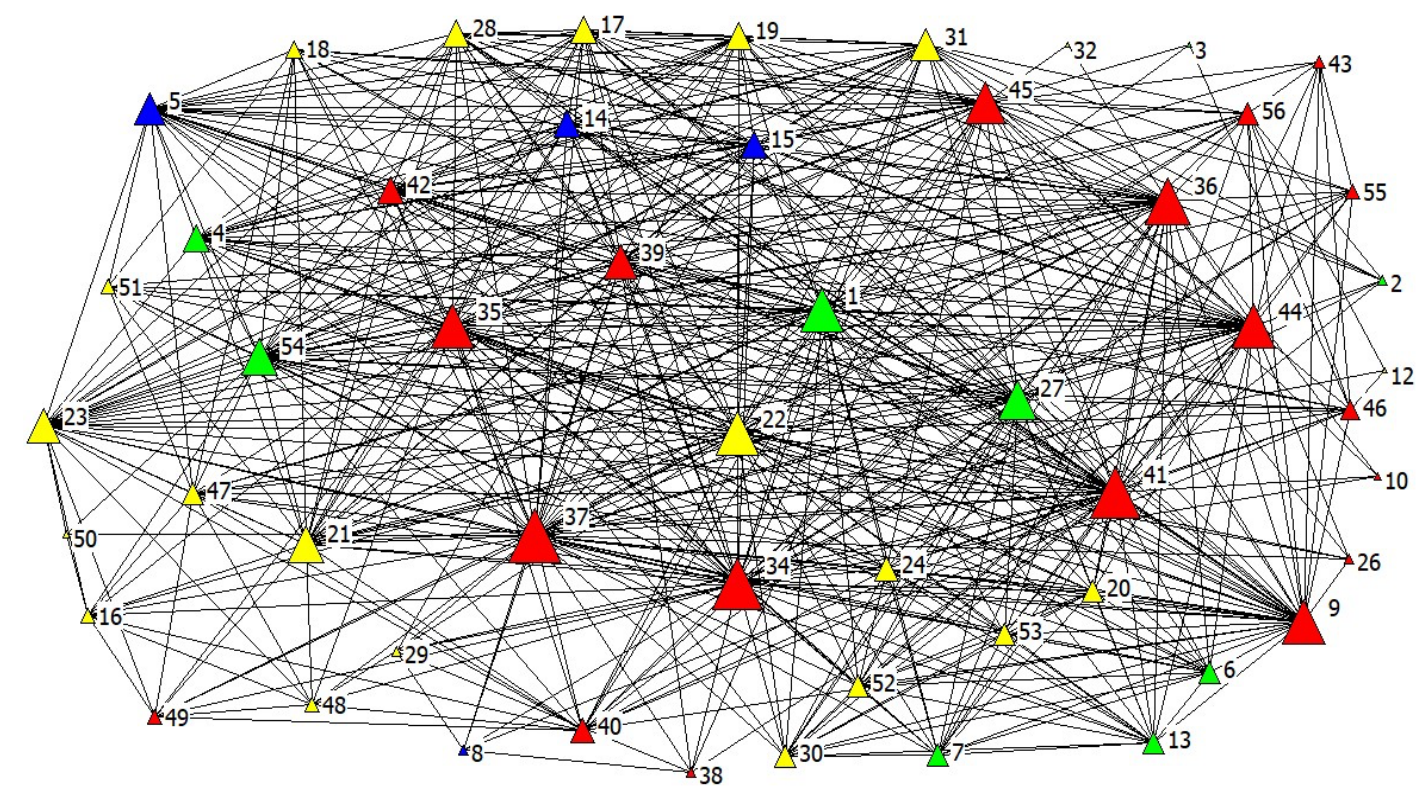

Source: Prepared by the author (2021).

initiative to develop an alternative program, with fewer resources and based on creative experiences and the exchange of resources among the participants in the script. With this change - in the interviewees' understanding - a Tourist Region of the Brejo was created with which local people identified.

The attitude towards the 2015 event, provoked by the reaction to the lack of resources from traditional sources in 2014, aroused strong feelings of belonging and identity, the strength of will and engagement among Forum members, as well as their understanding of the power of organization they have as members. This new awareness has been commonplace among participants in the Paths of Cold, at all levels, and in events ever since. This perception is reinforced by the pattern seen in the sociogram in Figure 4, in which the centrality of actors in the network is distributed in such a way that power is relatively shared.

This sociogram in Figure 4 shows the actors that have greater centrality in the network, those that are more connected, which is shown through the size of the triangle it represents, the larger the figure, the greater its connectivity or centrality. The degree of centrality is an index of access to information and resources that circulate on the network and the opportunity to influence or be influenced within it (Hanneman, 2001; Molina, 2006). The pattern observed shows a balance between the organizations that interact within the
Forum. It is a network of low centrality, since control is widespread among group members, which favors a more equal distribution of opportunities and limits on the exchange of resources. The highlight are the larger private companies (the sugar mills) and the city halls of the municipalities most engaged in Paths of the Cold, without the sociogram revealing any preponderance of some of them.

It should be noted that the presence of the Associação de Jovens Arte e Cultura (Association of Young Art and Culture) (AJAC) (1) and the Grêmio Morenense (27) in the central area of the network demonstrates an interesting movement on the role of organizations from the non-state public sphere in the Forum. The most plausible panorama for the presence of these organizations shows the relevance and representativeness of the Forum as a space for legitimate participation to give voice to those organizations that would otherwise be difficult to hear. The opportunity to be part of a group with other organizations from different spheres makes this governance structure approach what Batim, Fratucci and Trentin (2020) understand as an instrument of civil society's struggle for more participation and decisionmaking power in the process on-site tourism planning. 
Figure 5: Sociogram of the Degree of Intermediation of Actors in the Regional Forum Network of Sustainable Tourism of Brejo Between the Years 2009 To 2018

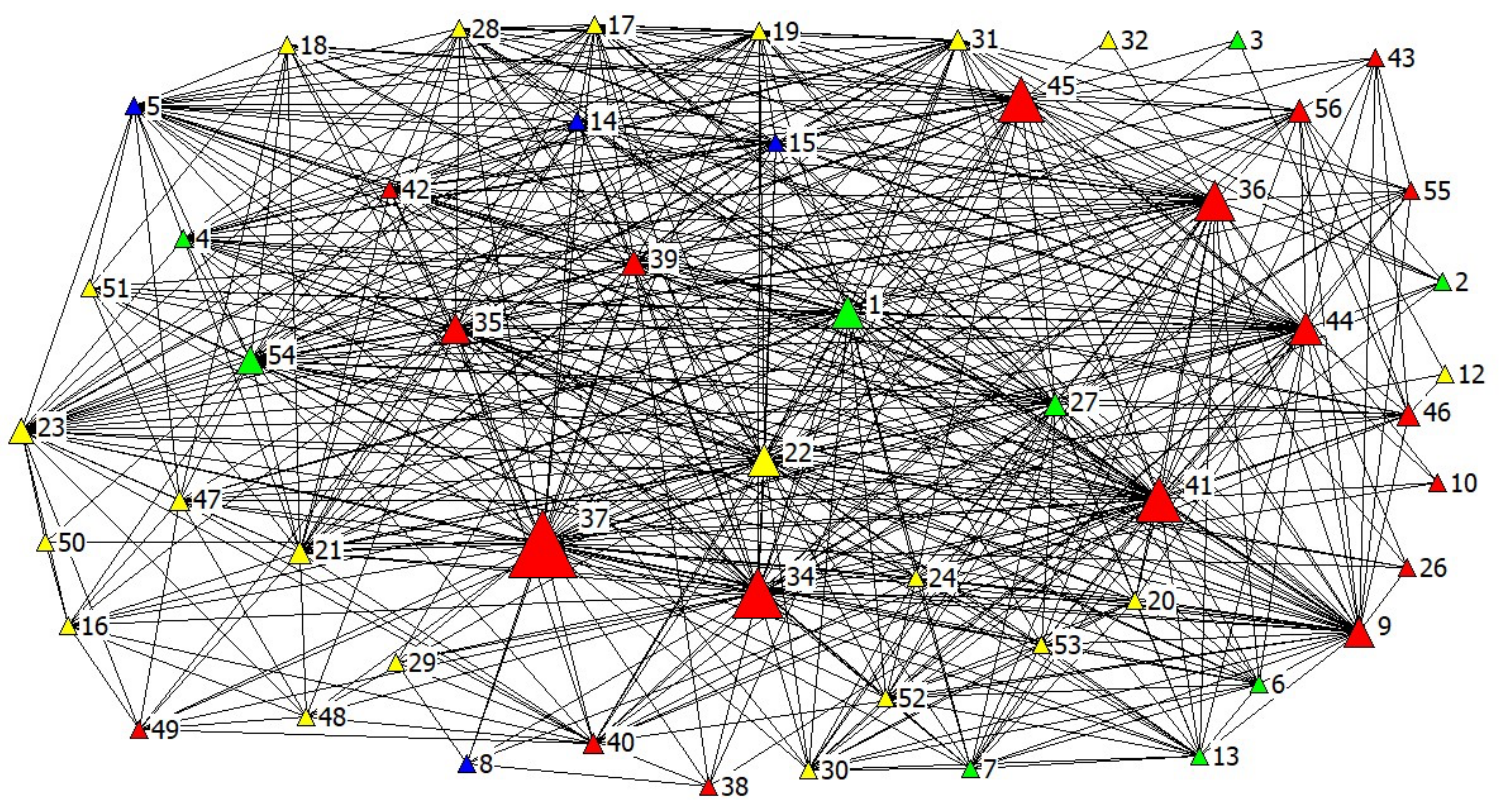

Source: Prepared by the author (2021).

The active participation of AJAC (1) and Grêmio Morenense (27) in the Forum is related to the demands of each one, but which largely reflect the national ills in the area. AJAC brings together young people, predominantly from the rural areas of the municipalities, with the objective of organizing themselves to discuss the demands for employment and better quality of life. In tourism there are the hopes of many of them, stimulated in training courses offered by educational institutions and training agencies and seduced by the discourse about the benefits that the activity brings. It is the opportunity to integrate and establish contacts with other organizations, especially those in the private sphere.

Grêmio Morenense is a centenary literaryrecreational entity, officially founded in 1924 and has a relevant role in the socioeconomic and historical context of the region and which, over the decades, has suffered from neglect of the local historical heritage. Since 2002 its headquarters is entitled Cultural Heritage of Solânea, which favored its reopening in 2005 and its inclusion in the Forum in 2007 as a founding member. The presence of Grêmio at the Forum is an opportunity to assert the maxim that tourism can contribute to the appreciation of the historical and cultural heritage of the Brejo and, in particular, that of its host city of Solânea.

Both AJAC and Grêmio Morenense are founding members of the Forum with the right to voice and vote, and their high attendance at meetings explains a good part of why they are central to the network. Now, the extent to which these demands are met by the flow of information and resources exchanged on the network is something else. The inferences made so far, and which give content to the network, are supported by the story told by the minutes and the practical result for these specific demands, only other theoretical-methodological approaches could account for meeting these demands.

The sociogram in Figure 5 shows the degree of intermediation of actors in the network, which indicates how often an actor is on the shortest path to connect two others that do not have direct relationships and do not even know each other. In the central part of the network thus elaborated, the main actors are placed in an intermediation position, that is, in an advantageous position since it is through them that the greatest amount of information and resources pass through. This is where the city halls and the central role in mobilizing the information and resources they have can be found, with special emphasis on the Municipality of Bananeiras (37), and with little less intensity, for the city halls of Alagoa Grande (45), Areia (36), Pilões (41), Solânea (45), but all of these have a leading role in the Paths of the Cold project.

The pattern observed in the sociogram (Figure 5) shows the power of intermediation that the 
Municipality of Bananeiras (37) has over other members of the same network, but who do not know each other, which gives the municipality advantages in terms of articulation to achieve its goals, as it is the fastest way to connect and mediate the flow of information and network resources.

The importance of Bananeira is justified by the uniqueness of the municipal government in investing in tourism in the early 2000 s, serving as an example and inspiration for other municipalities in the region to also invest in the sector. What drives the city's economy is the second-home tourism segment, under the face of closed condominiums, which extend over large rural areas of the city, bringing their benefits and harms, depending on which side you look at. But that's another matter.

Horizontalities and Verticalities in the Dynamics of the Forum

Of the tourist regions of Paraíba located beyond the waterfront, the Region of Brejo Paraíba is the one that has shown the greatest prominence. Its rich tourist potential contributes, without a shadow of a doubt, but that's not all. The regional agents involved in the activity, articulated through and around the Forum, have been working in this direction.

The constant presence of the same municipalities in the Forum (Table 02) gives them greater power of intermediation over the actors in the network. This pattern reinforces the perception of governance as "a State instrument to maintain its power under the aegis of valuing the place and community participation in decision-making" (Batim et al., 2020, p. 48). This also makes the Forum a subterfuge for maintaining its own interests and, consequently, it is subject to the convening power and operating rules of municipal governments (Burity, 2005).

Thus, in an attempt to make spaces for participation more efficient, the articulatory practice of training in networks is rewritten in terms of a collaborative relationship with the State, established by an organizational solidarity that leads the place to the rules of the established order. By organizing the processes, structured by the assumptions of network governance, the policy directs, through vertical flows, the guidelines for conducting national policies in the region. This is how the PRT must be understood, with the specificity, in Paraíba, of not having the SETDE (56) as an intermediation point between the municipalities, because despite its institutional power as the one attributed to it by the program, within the scope regional practically disappears in the transit of the effective articulations. The opportunities for participation opened up by verticalities give rise to practices and actions supported by a network of organic solidarity and collaboration, which meets the needs of the region, such as those described so far.

The network, as a space for debate and the search for consensus, also measures the limits defined by the competition between actors for more resources and more space. Converging with what Carvalho (2019) concluded in an analysis of the problems that occur in the Governance Instance in Maranhão, what is seen in the Forum are misunderstandings between members motivated by distrust and disagreement about the role played by each one in the elaboration of actions of the Paths of the Cold. It is noticed the resistance of some members to share resources when it comes to accepting the inclusion of new municipalities in the Cultural Route of a close schedule, even if these formally integrate the Tourist Region of Brejo and the Forum.

The case of the municipality of Solânea (45) is an example, as, despite being associated with the IGR since 2010 , it was only in 2014 that it was able to actually join Paths of the Cold. In 2011, the city halls participating in the event refused to share with Solânea the few resources granted by the state government to finance the cultural itinerary. Solânea would enter only under the condition of spending a certain amount to invest in its programming. However, the municipal manager at the time did not accept this condition, which led to a postponement of the municipality's entry into the itinerary. Despite this fact indicating/reflecting the influence of governmental discontinuity in policy management, this has not been reflected in the actions of the Forum considering the frequency of city halls in this space of participation.

The context of the dispute over financial resources is a reflection of their limitation, not only for Paths of the Cold, but for the maintenance of the Forum itself. The lack of own resources also undermines the possibility of hiring consultants that can develop projects that meet the requirements of the MTur public calls, which could help to consolidate regional tourism. This financial restriction is offset by the availability of others such as information, knowledge, skills, support, among other nonmonetized resources. Even so, the search for other 
sources of funds is an ongoing work of the Board, recorded by official letters and notices of meetings.

The historical trajectory of this IGR, which begins in 2005, with the first articulations for the realization of Paths of the Cold, shows the implementation of policies created in the Region itself, where the actors are articulated to undertake in a regionalized manner. In other words, horizontal forces are decisive in the tourism planning process in the Brejo Region, fulfilling the PRT's proposal to transfer to them the conduct of their own development. Considering this, based on the governance elements indicated by Nóbrega and Figueiredo (2014), the Forum do Brejo presents itself as a dynamic space for articulation and a positive experience of participation.

\section{Final Considerations}

The PRT is a state policy that, as stated, aims to plan tourism in the country in a regionalized and decentralized manner, and does so by transferring responsibility for its development to tourist regions. In Brejo da Paraíba, the definition of the Tourist Region took place in 2004 by the municipalities' compliance with the call of the PRT, starting a trajectory that was established in 2007 by the institutionalization of the Regional Forum for Sustainable Tourism of Brejo. Since then, the articulations between actors (state public, nonstate public, corporate and private) involved in the activity have been maintained based on their participation in the regional tourism planning process.

The main result of these articulations are events in the form of integrated itineraries such as Paths of the Cold, which in turn provides visibility to the region, arouses interest in new agents and in more municipalities and generates tourist flow. Therefore, a consolidated Tourist Region is less dependent on agents and forces external to the place, where actions generated by local actors predominate.

It is understood that the policy formulated by the macro-actors, in this case essentially represented by the State, in conditioning tourism planning at regional and local levels, takes place from an organizational solidarity established in a vertical, top-down manner, which defines the actions. This direction conditions the idealized structure of network governance, which makes room for the mobilization and empowerment of regional agents in carrying out these actions. In line with these guidelines, the Tourist Region of Brejo Paraíba and its Regional Governance Instance, by showing themselves more active than any other region, managed to execute and give visibility to the Paths of the Cold project, which was highly successful and repercussion.

The reticular approach has allowed us to deepen our knowledge of the network of relationships established between the various actors in the Forum. The first sociogram shows the dynamics of the actors and their presence at the meetings and provides an overview of their distribution in the network, by spheres of action, with the most frequent being those located in the central area of the network. The following sociogram shows the actors with the greatest centrality in the network, that is, those most connected. Thus, for example, the prominence of the cachaça plantations and the city halls of the municipalities with the greatest commitment is confirmed. Finally, the third and last sociogram indicates the actors who are in an intermediary position, with greater or lesser intensity. Highlight for the position of the Municipality of Bananeiras, as well as with a lot, but less intensity, of the city halls of Alagoa Grande, Areia, Pilões and Solânea, precisely those that play a major role in the Paths of the Cold project. This approach, together with field observations, allowed a better understanding of the object of study.

For all of the above, it can be concluded that the increase in tourism in the Brejo Tourist Region is the result, at least to a large extent, of a flow of horizontal actions, based on an organic solidarity resulting from the articulation between Forum members supported by municipal agencies that manage tourism, sometimes by the participation and performance of private and third sector agents. The most significant actions for regional tourism planning have been designed and managed within the region by these actors, in a more autonomous way.

To the question of whether there are more or less strong indications that the political actions articulated within the scope of the Forum have been contributing to the interiorization of tourism in Paraíba, the answer is clearly yes. The tourist phenomenon finally surpassed the waterfront and reached the Brejo region of Paraíba. Thus, it is possible to talk about the interiorization of tourism in Paraíba from this Region. Now, to what extent the activity influences and what it means for regional development is a question to be answered in future research. 


\section{References}

Avritzer, L. (2009). Experiências nacionais de participação social. Cortez Editora.

Bantim, N., Fratucci, A., \& Trentin, F. (2020). O papel do Estado nas instâncias de governança regionais do Turismo. Revista Acadêmica Observatório De Inovação Do Turismo, 14(2), 3958.https://doi.org/10.17648/raoit.v14n2.5734

Bresser-Pereira, L. C., \& Grau, N. C. (1999). Entre o Estado e o Mercado: o Público Não Estatal. In: Luiz Carlos Bresser Pereira \& Nuria Cunill Grau. (Coord.). O Público Não-Estatal na Reforma do Estado. Ed. FGV, 15-48. http://www.bresserpereira.org.br/documento/150 $\underline{7}$

Borgatti, S. P., Everett, M. G., \& Freeman, L. C. (2002). Ucinet for Windows: Software for social network analysis. Harvard, MA: analytic technologies, 6.

Brusadin, L. B. (2005). Estudo da avaliação do programa nacional de municipalização do turismo-PNMT na gestão do presidente Fernando Henrique Cardoso. Revista Hospitalidade, 2(2), p. 87-112. https://www.revhosp.org/hospitalidade/article/vie $\underline{\mathrm{w} / 223}$

Burity, J. A. (2005). Identidades coletivas em transição e a ativação de uma esfera pública não-estatal. In: Lubambo, A. et al.(Coord.). Desenho institucional e participação política: experiências no Brasil contemporâneo. Vozes, 63-107.

Carneiro, C. B. L. (2002). Conselhos de políticas públicas: desafios para sua institucionalização. Revista de Administração Pública - RAP, 36(2), p. 277-292. https://bibliotecadigital.fgv.br/ojs/index.php/rap/a rticle/view/6439/5023

Carvalho, F. C. (2019). Políticas públicas e governança territorial do turismo no estado do Maranhão. GeoTextos, $\quad 15 \quad$ (1), 157-179. file:///C:/Users/Usuario/Documents/Ana\%20Valer ia note/Textos\%20access/29354-114720-1-PB.pdf

Costa, S. R., \& Carvalho, C.M.B. (2014) Instância de governança regional: uma perspectiva para o desenvolvimento turístico do polo São Luís. Caderno de Pesquisa., São Luís, 21(n. especial), 2014 ,

$1-15$ http://www.periodicoseletronicos.ufma.br/index.p hp/cadernosdepesquisa/article/view/2597/0

Cohen, J. (2003). Sociedade civil e globalização: repensando categorias. Dados, 46(3), 419-459. https://doi.org/10.1590/s0011$\underline{52582003000300001}$

Coriolano, L. N. M. T. (2006) O turismo nos discursos, nas políticas e no combate à pobreza. Annblume,

Côrtes, S. (2005) Fóruns participativos e governança: uma sistematização das contribuições da literatura. In: Lubambo, Catia \& Coêlho, Denílson
B. \& Melo, Marcus A. (Coord.). Desenho institucional e participação política: experiências no Brasil contemporâneo. Vozes, 13-32.

Coutinho, A. C. A., \& Nóbrega, W. R. D. M. (2019). Governança em destinos turísticos: desafios na sociedade contemporânea. Revista Brasileira de Pesquisa em Turismo, 13, 55-70. Retrived from: https://rbtur.org.br/rbtur/article/view/1543

Degrandi, J. O., \& Silveira, L. L. S. (2013). Verticalidades e Horizontalidades na Função Comercial da Cidade de Santa Maria-RS. Mercator, Fortaleza, 12(29), 39-50 http://www.mercator.ufc.br/mercator/article/view 1953\#: :text=DOI\%2010.4215/RM0000.0000.0000

De Oliveira, J. R. (2018). "Do sítio sim, besta não!": reciprocidade, dons e lutas simbólicas em jogo no turismo em Areia, Paraíba-Brasil. [Tese de Doutorado, Universidade Federal de Pernambuco] Biblioteca de Teses e dissertações. https://repositorio.ufpe.br/handle/123456789/320 89

Draibe, S. M. A. (1998). A nova institucionalidade do sistema brasileiro de políticas sociais: os conselhos nacionais de políticas setoriais. Caderno de Pesquisa- NEPP-UNICAMP, (35), 125

https://www.nepp.unicamp.br/biblioteca/periodic os/issue/view/71/CadPesqNepp35

Empresa Paraibana de Turismo. (2014). Pesquisa do perfil do turista na Rota Cultural Caminhos do Frio - Comparativos consolidados de 2011, 2012, 2013 e 2014. João Pessoa.

Endres, A. V. (2014). As políticas de turismo no Brasil e os novos arranjos institucionais na Paraíba: o papel das organizações locais. In: Pimentel, T.D. \& Emmendoerfer, M.L. \& Tomazzoni, E. L.(Coord.). Gestão pública do turismo no Brasil teorias, metodologias e aplicações. EDUCS, p. 91124

Endres, A. V. (2003). Redes políticas como novo instrumento de condução política do Estado: contextualização frente à complexidade social e possibilidades para o planejamento turístico. Turismo - Visão e Ação. 5(3), 217238. https://siaiap32.univali.br/seer/index.php/rt va/article/view/1078

Endres, A. V. (2002). Planejamento estatal: do centralizado ao participativo e seus reflexos no planejamento do turismo no Nordeste. Turismo em Análise, São Paulo, (13)1, 1-114. https://www.revistas.usp.br/rta/article/view/6358 $\underline{0 / 66345}$

Endres, A. V. (2010). Panorama dos estudos sobre políticas de turismo na pós-graduação brasileira. VI Seminário de Pesquisa em Turismo do Mercosul. Caxias do Sul, Brasil. https://www.ucs.br/ucs/eventos/seminarios_semi 
ntur/semin_tur_6/arquivos/05/Panorama\%20dos \%20Estudos\%20sobre\%20Politicas\%20de\%20Tur ismo\%20na\%20Pos-Graduacao.pdf

Endres, A. V., \& Pakman, E.T. (2019). A governança das políticas de turismo: o papel dos espaços de participação na perspectiva da análise de redes e da teoria institucional. Revista Brasileira de Pesquisa em Turismo, 13(1), 1-18. https://doi.org/10.7784/rbtur.v13i1.1431

Fórum Regional do Turismo Sustentável do Brejo (FRTSB). (2010). Estatuto social. Bananeiras (PB).

Fórum Regional do Turismo Sustentável do Brejo (FRTSB). (2011). Regimento Interno. Solânea (PB).

Gomes, P. K. M. \& Silva, L. H. P. (2017). Políticas de turismo no Rio de Janeiro pós-fusão: programas para interiorização do turismo no estado. Revista Política e Planejamento Regional, 4(2), 251-27. http://www.revistappr.com.br/artigos/publicados/ Politicas-de-turismo-no-Rio-de-Janeiro-posfusao-programas-para-interiorizacao-do-turismono-estado.pdf

Goulart, S., Vieira, M. M. F., Costa, C. F. D., \& Knopp, G. D. C. (2010). Articulações em rede e acontecimentos no território: subsídios teóricos para a formação de políticas públicas para o desenvolvimento. Cadernos ebape. br, 8, 388-403.. http://www.scielo.br/pdf/cebape/v8n3/a02v8n3.pd $\underline{f}$

Hall, C. (2011). A typology of governance and its implications for tourism policy analysis. Journal of Sustainable Tourism, 19(4-5), 437-457. https://doi.org/10.1080/09669582.2011.570346

Hanneman, R. A. (2001). Introducción a los métodos del análisis de redes sociales. Riverside: Universidad de California.

Karnopp, E. (2014). Desenvolvimento regional entre verticalidades e horizontalidades: a agricultura familiar em questão. Revista do Departamento de Geografia - USP, 27(1), 282-295. https://doi.org/10.11606/rdg.v27i0.498

Keinert, T. (2007). Administracão pública no Brasil. Annablume.

Lavalle, A. G., Castello, G., \& Bichir, R. M. (2007). Protagonistas na sociedade civil: redes e centralidades de organizações civis em São Paulo. Dados, 50(3), 465-498. https://doi.org/10.1590/s0011$\underline{52582007000300002}$

Lopes, F., \& Baldi, M. (2009). Redes como perspectiva de análise e como estrutura de governança: uma análise das diferentes contribuições. Revista de Administração Pública, 43(5), 1007-1035. https://doi.org/10.1590/s0034$\underline{76122009000500003}$

Lowndes, V., \& Skelcher, C. (1998). The dynamics of multi-organizational partnerships: an analysis of changing modes of governance. Public Administration, 76(2), 313-333. https://doi.org/10.1111/1467-9299.00103

Marques, E. C. (2000). Estado e redes sociais: permeabilidade e coesão nas políticas urbanas do Rio de Janeiro. Revan/Fapesp.

Martins, L. (1998). Estado e sociedade: uma mudança de parâmetros. In: Sociedade e estado: superando fronteiras. FUNDAP, 35-44.

Ministério do Turismo. (2007) Programa de regionalização do turismo - roteiros do Brasil: introdução à regionalização do turismo. Brasília. Recuperado http://www.regionalizacao.turismo.gov.br/images $\underline{\text { roteiros brasil/introducao a regionalizacao do }}$ turismo.pdf

MTur. (2013). Programa de regionalização do turismo: diretrizes. Brasília. Recuperado de http://regionalizacao.turismo.gov.br/images/pdf/P ROGRAMA_DE_REGIONALIZACAO_DO_TURI SMO - DIRETRIZES.pdf

MTur. (2019). Regionalização: sensibilização e mobilização. Brasília. Recuperado de http://www.regionalizacao.turismo.gov.br/images Imtur-cartilha-promocional-final.pdf

Molina, S. \& Rodriguez, A. S. (2001). Planejamento integral do turismo: um enfoque para a América Latina. EDUSC.

Molina, J. L., Quiroga, A., Martí Olivé, J., Maya Jariego, I., \& Federico, A. D. (2006). Talleres de autoformación con programas informáticos de análisis de redes sociales. Bellaterra

Mota, L., \& Bittencourt, B. (2019). Governação pública em rede: contributos para sua compreensão e análise (em Portugal e Brasil). Tempo Social, 31(2), 199-219. https://doi.org/10.11606/01032070.ts.2019.147567

Nagabe, F. (2019). O turismo convencional e as políticas contra-hegemônicas em comunidades de espaços rurais da Paraíba. [Tese de doutorado, Universidade Estadual do Ceará]. Biblioteca de Teses e dissertações https://siduece.uece.br/siduece/trabalhoAcademic oPublico.jsf?id $=8323$

Nóbrega, W. R. M., \& Figueiredo, S. (2014). Turismo e gestão pública: uma avaliação das instâncias de governança no oeste do estado do Pará. In: Pimentel, T. D. \& Emmendoerfer, M. L. \& Tomazzoni, E. L. (Coord.) Gestão pública do turismo no Brasil: teorias, metodologias e aplicações. EDUSC, 431-461. 
Rodrigues, J. (2014). Políticas Públicas e Geografia: a retomada de um debate. GEOUSP: Espaço e Tempo, 18(1), 152-164 https://doi.org/10.11606/issn.21790892.geousp.2014.81093

Santos, M. (2001). Verticalidades e horizontalidades. In: Por uma outra globalização: do pensamento único à consciência universal. Record, 105-112.

Santos, M. (2006). Horizontalidades e verticalidades. In A natureza do espaço: técnica e tempo, razão e emoção. Ed. USP, 190-195.

Secchi, L. (2009). Modelos organizacionais e reformas da administração pública. Rev. Adm. Pública, 43(2), 347-369. $\quad$ https://doi.org/10.1590/S0034$\underline{76122009000200004}$

Silva, R., \& Fonseca, M. (2018). Os investimentos do Ministério do Turismo e o Programa de Regionalização do Turismo: desencontros da política governamental no interior potiguar. Caderno Virtual De Turismo, 17(3). https://doi.org/10.18472/cvt.17n3.2017.1207

Virginio, D. F., \& Ferreira, L. V. (2013). Gestão pública do turismo: uma análise da política de regionalização no período 2004-2011 no Rio Grande do Norte, Brasil. Caderno Virtual de Turismo, 13(2), 162-182. http://www.ivt.coppe.ufrj.br/caderno/index.php/ca derno/article/view/721

Xavier, T. R., Totti, K. Á. S., Raddatz, S., \& Flores, M. (2021). Aplicação do programa de regionalização do turismo em uma instância de governança regional no Estado do Rio Grande do Sul, Brasil. Turismo: Visão e Ação, 23, 86-109. https://doi.org/10.14210/rtva.v23n1.p86-109 


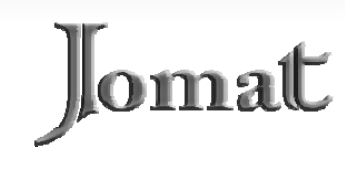

Journal of multidisciplinary academic tourism

ISSN: 2645-9078

2021, SP (1): 69-88

https://doi.org/10.31822/jomat.2021-SP-1-69

\title{
INFO PAGE \\ The regional forum of the sustainable tourism of Brejo and its role in the interiorization of tourism in Paraíba/Brazil
}

\begin{abstract}
In Paraiba, Northeastern Brazil, the sun and sea segment is the main responsible for the flow of visitors in the state, being the segment that receives the most government investments in planning and promotion, to the detriment of the interior regions that figure in the background. The main policy of Ministry of Tourism is the Tourism Regionalization Program, which aims to manage, structure and promote tourism in a decentralized manner, transferring the responsibility for its development to the tourist regions, thus opening up possibilities for the interiorization of the activity. The Paraibano Tourist Region is one of the few in the interior of the state that has a growing tourist movement and an organizational dynamism that makes it stand out from the rest. Thus, the question is: What are the determinants of interests that move between the order established by public policy and the horizontal relations, of a more organic nature, forged within the Region? Are there more or less strong indications that the actions guided by the Program and those implemented by the Regional Forum for Sustainable Tourism in Brejo have been contributing to the interiorization of tourism in Paraiba? That said, the main goal of this study is to investigate the performance of the Regional Forum for Sustainable Tourism of Brejo and its contributions to the process of interiorization of tourism in Paraiba. This is a descriptive and qualitative research that uses bibliographic and documentary data, as well as data collected in field visits. The reticular perspective was also used as a methodological resource. Data were analyzed and interpreted through the conceptual repertoire of the fields of Geography and Political Sociology for the understanding of local dynamics, guided by the verticality and horizontality imposed by public tourism policy in the Region. The conclusion reached is that the increase in tourism happens
\end{abstract}

Keywords: Public Tourism Policies, Tourism Regionalization Program/Brazil, Social Network Analysis

\section{Authors}

Full Name Author contribution roles

Ana Valéria Endres: Conceptualization, Methodology, Software, Formal analysis, Investigation, Resources, Data Curation, Writing - Original $100 \%$ Draft, Writing - Review \& Editing,

Author statement: Author(s) declare(s) that All procedures performed in studies involving human participants were in accordance with the ethical standards of the institutional and/or national research committee and with the 1964 Helsinki declaration and its later amendments or comparable ethical standards. Declaration of Conflicting Interests: The author(s) declared no potential conflicts of interest with respect to the research, authorship, and/or publication of this article

This paper does not required ethics committee report

Justification: This research was conducted before January 1, 2020. For this reason, it is exempt from "ULAKBIM TRDizin" criterion. 